\title{
The Maslahah Concept in the Islamic Finance Institutions
}

\author{
ELSY RENIE* \\ Candidate of Doctor Faculty of Law, Brawijaya University, INDONESIA \\ M.T. Haryono No.169, Ketawanggede, Lowokwaru, Malang, East Java 65145 \\ THOHIR LUTH \\ Professor of Law, Faculty of Law, Brawijaya University, INDONESIA. \\ M.T. Haryono No.169, Ketawanggede, Lowokwaru, Malang, East Java 65145 \\ SITI HAMIDAH \\ Associate Professor Faculty of Law, Brawijaya University, INDONESIA. \\ M.T. Haryono No.169, Ketawanggede, Lowokwaru, Malang, East Java 65145 \\ SIHABBUDIN \\ Associate Professor, Faculty of Law, Brawijaya University, INDONESIA.
}

M.T. Haryono No.169, Ketawanggede, Lowokwaru, Malang, Malang, East Java 65145

\begin{abstract}
The sharia economy has grown rapidly in Indonesia for the past three decades. Sharia finance is an inseparable part of the Islamic economy. The market share of sharia finance in Indonesia consists of sharia banking, sharia insurance, sharia finance, sharia mutual funds, government sukuk and sharia stocks. In addition, there are still Islamic social finance sectors such as zakat and waqf. The development of sharia finance in Indonesia has undergone improvements from the previous stages. Studies that initially revolved around halal - haram, and seemed to repeat the classic debates, began to open to the renewal of Islamic law. As Fazlur Rahman said that Islamic law (in terms of fiqh) is not a rigid, and sacred thing towards changes because Islamic law is required to be able to provide juridical answers to various demands and issues of human life, while the dynamics of life always tend toward changes. Therefore the study of Islamic law in Indonesia must always be opened and it pays attention to the social implications from the application of law thoughts, and how the objectives of Islamic law (Maqashid Syari'ah) are manifested in the development of modren syari'ah financial industry. This study is a normative research, with a historical and analytical approach. The researcher concluded that, the realization of Maqashid Syariah in Islamic finance was a necessity. The products, the governance and the management of financial companies must be in order of Hifz ad-Diin, Hifz nafs, Hifz Aqal, Hifz Maal, Hifz Nasab, to achieve the benefit for the people and the advance of national economic development.
\end{abstract}

Keywords: Maqashid Syari'ah, Sharia finance, Islamic economy, Islamic law

DOI: $10.7176 / \mathrm{JLPG} / 87-12$

Publication date:July $31^{\text {st }} 2019$

\section{Introduction}

As a country with the largest percentage of Muslim population in the world, which reached $87.18 \%$, Indonesia has an opportunity for the development of Indonesia's Islamic economy. The Muslim population in Indonesia, which reached $87.18 \%$, has the opportunity to develop Islamic economics. This amount is a huge market share of economic and financial-based products and services. This is supported by the upward trend in consumption of halal goods and services, which are estimated to have high growth.

In fact, Indonesia is a bit late in developing the Islamic economy. The official of financial institution with sharia principles in Indonesia, it was only established in 1992, namely Bank Muamalat Indonesia. However, entering this third decade, many studies of Islamic financial institutions have developed in the form of banks, insurance, and Islamic finance institutions. Seeing this development, the Indonesian Ulama Council (MUI) in 1999 formed a National Sharia Council consisting of Islamic scholars and economic practitioners. Through this council, MUI conducted studies that were used as guidelines in implementing sharia economy in Indonesia.

Islamic finance is not only about religious preferences, but through Sharia Objectives (Maqasid al Sharia), Islamic finance has the latent power to play an important role in empowering individuals and communities, promoting an entrepreneurial culture, investing in a real and sustainable economy that benefits the wider community and the Indonesia's economy. Islamic finance is a real force for Indonesia by utilizing its economic dynamics but not its religious arguments. Formulated policies in the financial sector will create an enabling environment for this industry to channel its potential and play an important role in building a national economy that is in line with the goals of sharia and the priorities of the Government of Indonesia. 


\section{RESEARCH PROBLEM}

What is the manifestation of Maqashid Shari'ah in the Modern Financial Industry?

\section{DISCUSSION}

\section{MAQASHID SYARI'AH CONCEPT}

In terms of terminology, the purpose of Islamic Sharia in Arabic is called Maqashid al-Shari'ah al-Islamiyah. The understanding of these meanings has two-way implications, namely the intended target and the guaranteed reward promised to the object. The objectives addressed by the Islamic Shari'ah are humans, both in their status as servants of Allah and as Khalifah. The aim of the Shari'ah towards this goal is to inform, warn and show how the existence of humans who deny it. Regarding the rewards promised to humans are in the form of kindness, happiness in world affairs and the hereafter(Thohir,2011)

As the goal of Islamic law is maslahat, the laws applied are certainly for the benefit of the community. The purpose of shari'ah or Islamic law is to gain maslahat and to prevent from madharat and mafsadat. The original meaning of the word maslahah is benefit, a plural word from mashaha. According to Al-Syaukani, what is meant by mashlahah is maintaining the purpose of Islamic law and rejecting the disaster or dubious damage of human beings. (Hamidah,2017)

Ash-Syathibi (d. $790 \mathrm{H}$ ) also explained that in every sharia law there is 'illat, with the understanding that 'illat is a sign and muarrif of special law. Az-Zarkasyi commented that the law is not mu'allal, means that Allah SWT does something not for certain purposes, and no one obliges Him to do something. But Allah is able to bring mashlahat even without cause, and eliminate madharat even without tools.(Hamidah, 2017)

Al-Izz bin Abdussalam (d. 660 AH / 1261 AD) said, Anyone who pays attention to the essence of Shari'a, in an effort to bring about maslahat and reject mafsadat, he will gain deep conviction and knowledge that maslahat must not be ignored and mafsadat cannot be approached, although there is no ijma', text and qiyas that specifically discuss it in which it is because the core understanding of Shari'a requires it.( 'Izzuddin,2000)

The number of Shari'a texts is very limited and the text response to the new problems that arise, does not necessarily quickly be explored. However, by returning the text to the original philosophy, it will be able to know which text is desired and which one is not. Thus, the parameters are maslahah and mafsadah. If maslahat is dealing with the desired by the Shari'a, then the mafsadah is opposed by the Shari'a.('Izzuddin, 2000)

The main purpose of Islamic law is to realize maslahah for human life, it can be said that the establishment of Islamic law is closely related to the dynamics of maslahat that develops in the society. Mustafa Syalabi asserted that the change of law was due to changes of maslahat in the society (tabaddul al-ahkâm bi tabaddul almashlahah). The existence of an-nasakh (the deletion of a previous law with a new law), at-tadarruj fi at-tasyri $\hat{\imath}^{\prime}$ (stipulation of the law gradually) and nuzûl al-ahkâm which always follows the events that occurred during the revelation, all are the signs which clearly show that the changes of law follow the alteration of the existing problems.( Syalabi,1981).

The barometer of maslahah in Islam is Islamic law, not the human reason. Al-Ghazali explained that according to its origin, maslahah means something that brings benefits and keeps the harm (damage) which is essentially maintaining the goal of syara' in establishing the law. According to the purpose of the effort to find and establish the law, the maslahah is also called munasib or the harmony of maslahat with the purpose of the law. So, the main rules as the main purpose of Islamic law is to realize maslahah for human life, or in other word, the establishment of Islamic law is closely related to the dynamics of maslahat that develops in the society. Mustafa Syalabi asserted that the change of law was due to changes of maslahat in the society (tabaddul alahkâm bi tabaddul al-mashlahah). The existence of an-nasakh (the deletion of a previous law with a new law), at-tadarruj fi at-tasyrî́' (stipulation of the law gradually) and nuzûl al-ahkâm which always follows the events that occurred during the revelation, all are the signs which clearly show that the changes of law follow the alteration of the existing problems. ( Mustafa,1981)

The barometer of maslahah in Islam is Islamic law, not the human reason. Al-Ghazali, explained that according to its origin, maslahah means something that brings benefits and keeps the harm (damage) which is essentially maintaining the goal of syara' in establishing the law. According to the purpose of the effort to find and establish the law, the maslahah is also called munasib or the harmony of maslahat with the purpose of the law. So that there is a main rule as said by Muhammad Sa'id Ramadhan al-buti "where there are maslahat there are laws." Maslahat are divided into three types, namely. (Amir ,1993)

1) Masalahah al Mu'tabarah, are maslahah calculated by syara', because there are instructions from syara' both directly and indirectly, where the clue to the existence of this maslahah is the reason for establishing the law.

2) Maslahah Al-Mulghah, or rejected maslahah. It is maslahah that is considered good by reason, but it is not considered by syara' and there are syara' instructions that reject it. Here, the reason considers it as good thing which is in line with what is demanded by the problem.

3) Maslahah Mursalah, or called istishlah, what is deemed good by reason, in line with the purpose of the 
law of shara', but there is no guidance that calculates and rejects it to establish the law.

Al-Buti confirmed the theory of Maqashid Shari'ah Imam al-Syatibi by perceiving al-Maslahah as follows: wherever al-maslahah was found for mankind, that is where God's law was established. Therefore it is not appropriate to do a rigid act on the Qur'an and Hadith passages, also the fatwas of previous scholars. In addition, it is not appropriate to close themselves to the current and the present development. (Amir Syarifuddin, 1993)

Based on Ibn al-Qayyim's research on the texts of the Qur'an and Al-Sunnah, he finally concluded that Islamic shari'a was built for the benefit of humanity and universal humanitarian goals of justice, mercy, benefit and wisdom for life. So, these principles must be the basis and substance of all the problems of Islamic law. The deviations of these principles mean that they are contrary to the ideals of the shari'ah or religion. Thus, every decision that is unjust and merciless, is not Islamic law.

\section{THE IMPLEMENTATION OF ISLAMIC NORMS IN THE FINANCIAL INDUSTRY}

The concept of company is a business entity which involves many parties in achieving its objectives. For this reason, the corporate accountability for interested parties in the company is urgently needed. Shari'ah enterprise theory is a theoretical concept that is able to provide the basis in the formation of accounting principles and techniques that produce forms of accountability and information needed by stakeholders in sharia companies. In the Shari'ah enterprise theory, what applies is Allah SWT as the main source of trust, because He is the sole and absolute owner, while the resources possessed by the stakeholders in principle are a mandate from Allah, which attached to it an obligation to utilize it in the manner and purpose set by The Trustee. Therefore, in the Islamic company the responsibility of the company is not limited to the owner of the company, but rather to the responsibility to Allah SWT.

The Financial System is an important means in the civilization of modern society. The main objective is to raise funds from the community and channel them to the borrowers and then use them to be invested in the production and investment sectors. Besides, it is being used to buy goods and services so that economic activities can grow, develop and improve living standards. Therefore the financial system is a very basic thing in the economy and life of the people.

In Islam, economic behavior and commercial transactions cannot be separated from values and ethics. Islamic values are intended to direct and regulate human behavior in daily economic life. According to Abul Hassan and Sabur Mollah that Islamic financial thinkers state that an economy based on ethical values and Islamic principles must produce an economic system based on morals, not only serving the desires of Muslims but also humanity in general. At the basic level, there are three key components of Islamic ideology: tauhid, nubuwwah, and ma'ad. Tauhid refers to the oneness of God, while nubuwwah refers to the concept of prophethood.

According to Bambang Bodjonegoro(Kemenkeu, 2019), Sharia Finance is not only limited to religious preferences, but also further to achieve the goals of sharia (Maqasid al Sharia), where it plays an important role in empowering communities and individuals, encouraging self-employment, investing in the real and sustainable economy. The Islamic finance industry is currently still dominated by Islamic banking with total assets as of January 2019 reaching 479.17 trillion rupiahs or around 5.95 percent of 8.049 trillion rupiahs in the total national banking. While for the same period of the Islamic non-bank financial industry (IKNB), its assets were recorded at 101,197 trillion rupiahs with a market share of 5.81 percent of the total national IKNB assets which reached 1,741 trillion rupiahs. In terms of Islamic finance, State Sukuk or State Sharia Securities (SBSN) itself, it accounted for 18 percent of the total issued government bonds of 682 trillion rupiahs as of March 2019.(Kemenkeu, 2019)

In the Syari'ah Indonesia Financial Architecture Masterplan, (Bappenas, 2016) Indonesia has a unique sharia governance framework in the world. Comparing to many other frameworks, where the independence of Islamic scholars while making decisions is always debated caused by the possibility of conflicts of interest, the Indonesia Islamic finance industry has developed its own unique framework led by the National Sharia Council of the Indonesian Ulama Council (DSN-MUI). It maintains its independence by not having a relationship with the central bank, regulatory institutions, or other government institutions or departments. This institution operates under the Indonesian Ulama Council and provides all of the guidelines regarding sharia rules independently.

The profit sharing system offers a solution in which every business will experience profit or loss, so it is not rational when the economy only adopts one condition of the two economic conditions. Therefore, profit sharing businesses must be in accordance with sharia principles, not permitted to contain elements of usury, gambling and gharar, prohibited from producing illicit goods (pork and khamr). The proportional benefits are shared between banks and customers. Islamic banks can conduct buying and selling transactions with employers and customers, using murabahah, ijarah, istisna and salam schemes. Thus, the government authority has the courage in making policies and developing sharia-based financial institutions in the country that contain very high maslahah values. 


\section{THE EPISTEMOLOGY OF ISLAMIC LAW RENEWAL IN ECONOMICS}

Fazlur Rahman (Manan, 2005) said that Islamic law (in terms of fiqh) is not a rigid and sacred thing for changes, because Islamic law is required to be able to provide juridical answers to various demands and issues of mankind and human life, while the dynamics of life always lead to changes. Therefore, the opportunity to study Islamic law in Indonesia must always be opened, and it must pay attention to the social implications that come from the application of legal thoughts, while still maintaining its relevance to the will of the doctrine of the Qur'an and the Sunnah about human behavior.

Understanding Islamic law contextually is a necessity so that Islamic law is always aspirational, accommodating, and relevant to the times. Contextual understanding requires the use of reasoning power of Muslims who are popularly known as ijtihad. As expressed by Fazlur Rahman that the door of ijtihad has never been closed as long as the changes in the situation and conditions are still ongoing. The demands of ijtihad, especially in mu'amalah, are currently very large and urgent, especially in economic and financial matters.( Fazlur, 1995)

Noul j. Coulson, in his book A history of Islamic Law divides the pattern of Islamic law renewal in Indonesia, namely: Firstly, the codification of Islamic law becomes a positive law in the country known as the siyasah doctrine; Secondly, Muslims are not bound to one thought school only, which is called the takhayur doctrine and select which opinions are the best and dominant in the community. Thirdly, the development of new law arises, which is called the doctrine of tatbiq. Fourthly, new legal changes arise called as ijtihad or neo ijtihad. (Coulson' 1964)

Modernists in Indonesia are trying earnestly to reinterpret the understanding, the thoughts and the opinions of Islamic issues carried out by the previous scholars to be adapted to the times. So this renewal is the result of thoughts or opinions, not renewing or changing what is in the Qur'an and Sunnah. Modernization is a rationalization for obtaining usability in thinking and working optimally, for the happiness of mankind. This concept is always recommended by Fazlur Rahman in almost all the books he wrote, by referring to the methodology of the Qur'an, as-Sunnah, Ijtihad, Ijma' which was subsequently born as a product of state legislation.( Coulson' 1964)

The absorption of Islamic law into the Indonesian legal system is not something new, it has a long history since the Dutch colonial period. But since Indonesia's independence the absorption of Islamic law into the national legal system has increasingly become apparent, such as the birth of Law Number 1 of 1974 concerning Marriage (Law 1/1974), Law Number 41 of 2004 concerning Waqf (Law 41/2004), Law Number 19 of 2008 concerning State Sharia Securities (Law 19/2008), Law Number 21 of 2008 concerning Islamic Banking (Law 21/2008), Law Number 23 of 2011 concerning Management of Zakat (Law 23 / 2011), Presidential Instruction No. 1 of 1991 concerning Dissemination of Compilation of Islamic Law (Inpres 1/1991), and Supreme Court Regulation Number 2 of 2008 concerning Compilation of Sharia Economic Law (Perma 2/2008). The law concerning limited liability company is revised in 2007 which explicitly defined the role of DPS in companies that run businesses in sharia. From the other side, it is observed that in Indonesia, the absorption of private Islamic law is more easily accommodated into national regulations than any other areas of Islamic law. (Renie, E, et.all, 2019)

\section{ESTABLISHING MAQASHID SHARIA IN THE MODERN FINANCIAL INDUSTRY}

According to Muhammad Djakfar,( Muhammad Djakfar, 2015) Islam teaches that in order to reach the welfare of the world, it is necessary to protect the five things as contained in the teachings of maqashid as-Shari'ah which include the protection of religion, soul, mind, lineage and wealth. These five things need to be considered by producers for the safety of consumers in carrying out their lives. However, the ta'awun principle needs to be prioritized between interested parties on the basis of mutual benefit from one another.

In surah al-A'raf verse 180, surah al-Isra' verse 110 and surah Thaha verse 7-8, they give a message to Muslims that every business actor before his professional activity needs to understand the theological paradigm of business; from God, because of God and for God. It means that the business actors must be honest, fair, open, and have intentions only because of God. Because in the Al-Qur'an, there is guidance of doing business to be in accordance with Islamic shari'a., (Djakfar, 2015)

The presence of Islamic finance institutions is also based on maslahah. The interest-based economy has created a chaotic pattern of financial interactions. Ali Sakti (2007: 230) revealed that the interest made the unbalanced of the world financial system. The poor and the developing countries must continue to depend financially on modern countries. The nature of pre-determined returns from interest will make the behavior of capital holders tend to use their money as a tool to generate income through the financial sector rather than profit through productive activities in the real sector. Based on market rationality, interest or usury systems actually make the irrational of market mechanism. With interest, the market is always forced to be positive, all business units are always in a profit condition, of course this is not possible. It has a huge negative effect on both the economic level and social activities. The economic performance was hampered, and the public purchasing power 
declined and the inflation rose sharply. Ali Sakti ( Ali Sakti, 2007) said that the profit sharing system offers a solution in which every business will experience profit or loss, so it is not rational when the economy only adopts one condition of the two economic conditions. Therefore, profit sharing businesses must be in accordance with sharia principles, not permitted to contain elements of usury, gambling and gharar, prohibited from producing illicit goods (pork and khamr). Proportional benefits are shared between banks and customers, Islamic banks can conduct buying and selling transactions with employers and customers, using murabahah, ijarah, istisna and salam schemes.

Syari'ah's financial system which is included in the mainstream of the National strategy contains maslahah values from various aspects of the people, nation and religion. For this reason, modern sharia-based Islamic financial institutions in Indonesia need to be developed and supported in order to create an economic system inspired by uluhiyah, nubuwwah, trustworthy, fair and balanced.

\section{CONCLUSION}

The Syari'ah Financial Industry in Indonesia has proven to be a pillar of the national economy, it can be seen from the sukuk (State Islamic Securities) that have been able to finance infrastructure development in Indonesia, and attract foreign investors to invest in Indonesia. As well as banking institutions and other non-bank financial institutions, the realization of maqashid shari'ah is an effort to obey sharia principles which are supervised by the DPS, the attitude of ihtiyath (caution) in safeguarding and carrying out this shari'ah finance in accordance with the guidelines outlined in the fatwa and some of which have been absorbed in Indonesian legislation. It is an attempt to find maslahah while rejecting the mafsadat brought by the interest system or the conventional financial system. Although in its development it is also necessary to evaluate and improve from time to time, so that the Islamic financial institutions can be a blessing for all people, and can provide protection against five things as contained in the teachings of maqashid as-Shari'ah which include protection for someone religion, soul, mind, lineage and wealth.

\section{BIBLIOGRAPHY}

[1] Thohir Luth, (2011), Syari'at Islam mengapa Takut?, Malang, UB Press.

[2] Al-Syaukani., Irsyad al Fuhul Ila Tahqiq al Eal min 'ilm al-Ushul, Beirut, Libanon, Dar al-Fikr)

[3] 'Izzuddin bin Abdussalam, (2000), Qawa'id al-Ahkam fi Ishlah al-Anam., Damaskus, Dar al-Qalam.

[4] Al-Ghazâli, Abu Hamid Muhammad, (1997), al-Mustashfa, Beirut, Mu'assasah ar-Risâlah.

[5] Kementrian Keuangan Indonesia, Media Keuangan, VOLUME XIV / NO. 140 /MEI 2019

[6] BAPPENAS, (2016), Masterplan Arsitektur Keuangan Syariah Indonesia, Juli 2016

[7] Bagir Manan, (2005), Reformasi Hukum Islam di Indonesia, Jakarta, Raja Grafindo.

[8] Syalabi, Muhammad Mustafa, (1981), Ta'lîl al-Ahkk̂̂m, Beirut, Dâr an-Nahdhah al-'Arâbiyah.

[9] Muhammad Said Ramadhan Al- Buti, (1977), Dhawabit Al-maslahah fi al-Syari'ah al-Islamiyah, Beirut, Muassal al-Risalah.

[10] Amir Syarifuddin, (1993), Pembaharu Pemikiran Dalam Hukum Islam, Padang, Angkasa Raya

[11] 'Abd Allah Bayyah, Amali al-Dilalat wa Majali al-Ikhtilafat, (Beirut: Dar al- Minhaj, 2007),

[12] Muhammad Sa'id Ramadhan,(1986), Dawabit al-Maslahah fi sy-Syari'ah al-Islamiyah, Beirut, Muassasa ar-Risalah,

[13] Nova Rini, The Implementation of Islamic Corporate Governance (ICG) on Sharia Banking in Indonesia, The International Journal Of Applied Business Tijab, Volume 2 Nomor 1, April 2018, e-ISSN 2599-0705 Rini, N. (2019). The Implementation of Islamic Corporate Governance (ICG) on Sharia Banking in Indonesia. The International Journal of Applied Business, 2(1), 29-38

[14] Fazlur Rahman, (1995), Islamic Methodology in History, terjemahan Anas Mahyudin, Membuka Pintu Ijtihad, Bandung, Pustaka, 1995.

[15] Noul J. Coulson, (1964), A History of Islamic Law, Edinburgh University Press.

[16] Renie, E., Luth, T., \& Hamidah, S. (2019). The Legal Construction of Sharia Capital Market in Indonesia. JL Pol'y \& Globalization, 82, 32. 